\title{
Ex Situ Biodegradation of Crude Oil Using Bacterial Isolates From Palm Oil Mill Effluent
}

\author{
Amechi Sampson Nwankwegu*, Emmanuel Michael Ikpe, Edna Ifeoma Chukwura, \\ Richard Chidiebere Irondi, Emmanuel Ifeanyi Obika
}

Department of Applied Microbiology and Brewing, Nnamdi Azikiwe University, Awka, Anambra State, Nigeria

Email address

smetchie@yahoo.com (A. S. Nwankwegu)

${ }^{*}$ Corresponding author

\section{To cite this article:}

Amechi Sampson Nwankwegu, Emmanuel Michael Ikpe, Edna Ifeoma Chukwura, Richard Chidiebere Irondi, Emmanuel Ifeanyi Obika. Ex Situ Biodegradation of Crude Oil Using Bacterial Isolates From Palm Oil Mill Effluent. American Journal of Life Sciences.

Vol. 4, No. 3, 2016, pp. 71-75. doi: 10.11648/j.ajls.20160403.11

Received: May 18, 2016; Accepted: May 27, 2016; Published: June 14, 2016

\begin{abstract}
Bioremediation of crude oil is quite unique, complex and relatively a slow process. They study area for this research work was a cottage industry located in Orumba North local government area of Anambra state, Nigeria. Evaluating the degradation potential of bacterial isolates from palm oil mill effluent on crude oil was conducted using standard methods, which includes screening, inoculums development and degradation studies to assess the most promising hydrocarbon degraders. Pooled samples collected from different points on the palm oil mill effluent disposal channels were inoculated mineral salt medium containing crude oil to assess degradation abilities of different bacterial species. Data indicated that these bacterial isolates were capable of thriving in the mineral salt medium between the $\mathrm{pH}$ range of 6.0-7.0 and bacterial proliferation were quantified by assessing the total viable count which ranged between $2 \times 10^{5}-9 \times 10^{5} \mathrm{cfu} / \mathrm{ml}$ based on individual abilities to utilize crude oil as a sole carbon source. Cultural, morphological and biochemical characterizations were conducted on these isolates and Bergey's manual of determinative bacteriology was used to suggest possible isolates, while molecular identification was done Centre for Agriculture and biosciences International (CABI), UK using partial 16S rDNA sequencing analysis and FASTA algorithm with prokaryote database from EBI. Escherichia fergosonii, Klebsiella variicola and Microccocus luteus were identified. Gas chromatographic analysis was applied to quantify the extent of degradation of crude oil by the isolates. All the isolated bacterial species displayed varying degree of crude hydrocarbon biodegradation.
\end{abstract}

Keywords: Palm Oil Mill Effluent, Crude Oil, Biodegradation, Bacteria, Ex Situ

\section{Introduction}

Crude oil is the major source of energy for industry and daily activities. Crude oil has been known to belong to the carcinogenic and neurotoxic family of organic pollutants. Accidental leakages and spillages occur at regular intervals during the exploration, production, refining, transportation and storage of crude oil. The amount of natural crude oil seepage was estimated to be 600,000 metric tons per year with a range of uncertainty of 200,000 metric tons per year [1]. Biodegradation of crude oil in natural ecosystem is a very slow and complex process thet requires the microbial transformation into a toxic and approximately non-toxic for as well as utilization as a biosynthetic substance [2].
Crude oil contaminated environments loose it fertility and agricultural seeds/plants also loose viability. Hence, inhibiting agricultural yields [3]. Bioremediation of crude oil contaminated environments has been very reliable due to the exposure of certain oil tolerant microbial species with biodegradable potentials or genetically modified for efficiency targeted towards oil utilization [4]. The application of microorganisms from palm oil mill effluent (POME) in the remediation of crude oil and other saturated/unsaturated hydrocarbon is a cutting-edge research area of solving crude oil spillage problems [5]. This research work is designed at determining the crude oil degrading bacterial isolates from palm oil mill effluent, examining the most suitable bacterial strain (s) to serve as 
potential seeders for crude oil contaminated sites was also evaluated.

\section{Materials and Methods}

\subsection{Study Area}

Small cottage oil palm processing industry was visited at Ufuma in Orumba North local government area of Anambra state, Nigeria. Pooled sample of raw palm oil mill effluent (POME) was collected from different points of the effluent discharge channels.

\subsection{Sample Collection}

Samples were collected into sterile plastic bottles specified for collecting liquid effluent samples after which they were carefully transported in an ice box at $4^{\circ} \mathrm{C}$.

The crude oil used in this experiment was purchased from Eleme refinery in Port Harcout and stored in dark at ambient temperature throughout the study. Before used, the crude oil was sterilized at $121^{\circ} \mathrm{C}$.

\subsection{Physicochemical Analysis of Palm Oil Mill Effluent}

Determination of $\mathrm{pH}$ of the sample using $\mathrm{pH}$ meter with 5:1 sample and distilled water ratio $[6,7]$.

\subsection{Culturing Condition/Inoculation}

The mineral salt medium contained the following salts; $1.2 \mathrm{~g}$ of $\mathrm{KH}_{2} \mathrm{PO}_{4}, 1.8 \mathrm{~g} \mathrm{~K}_{2} \mathrm{HPO}_{4}, 0.2 \mathrm{~g} \mathrm{MgSO}_{4} .7 \mathrm{H}_{2} \mathrm{O}, 4.0 \mathrm{~g}$ $\mathrm{NH}_{4} \mathrm{Cl}, 0.1 \mathrm{~g} \mathrm{Nacl} 0.01 \mathrm{~g} \mathrm{FeSO}_{4} .7 \mathrm{H}_{2} \mathrm{O}$ dissolved in $1000 \mathrm{ml}$ distilled $\mathrm{H}_{2} \mathrm{O}$. Nutrient broth and mineral salt medium (MSM) as modified by [8] were the liquid media and mineral salt oil agar was the only solid medium used. Bacterial isolates where maintained in a liquid mineral salt medium. The experiment was set-up by artificial pollution of the palm oil mill effluent with sterilized/filtered crude oil using test-tube method.

\subsection{Screening Test for Hydrocarbon (Crude Oil) Utilization}

The medium used to study the crude oil utilization ability by the bacterial isolates was a mineral salt medium containing $4 \%(\mathrm{v} / \mathrm{v})(0.2 \mathrm{ml}$ in $5 \mathrm{ml}$ of mineral salt $)$ of the crude oil. The medium was made out in $30 \mathrm{ml}$ test tube containing $5 \mathrm{ml}$ of the mineral salt medium and sterilized as stated before. Incubation was done at $30^{\circ} \mathrm{C}$ for two week with a loopful of bacterial isolates in a test tube shaker. The optical densities of the cultures were measures at $550 \mathrm{~nm}$ with the aid of a colorimeter to study the efficiency of the isolates based on utilization abilities of the crude oil as a sole carbon source.

\subsection{Inoculums Development}

The most potent bacterial crude oil be grading isolate with high utilization ability was chosen for the degradation test. Mineral salt broth containing $0.3 \mathrm{ml}$ of crude oil was dispensed in $30 \mathrm{ml}$ quantities in $250 \mathrm{ml}$ Erlenmeyer flask with 5 loopful of the isolated and incubated at $30^{\circ} \mathrm{C}$ for 24 hours at $120 \mathrm{rpm}$ in a shaker. pH (Fig. 1), optical densities (OD) at 550nm wavelength of individual flask (Fig. 2) and Total viable count (Fig. 3) were measured.

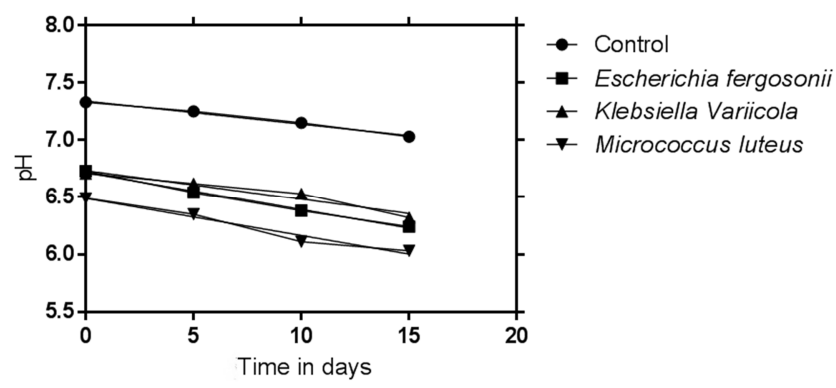

Figure 1. Change in $\mathrm{pH}$ with time in days.

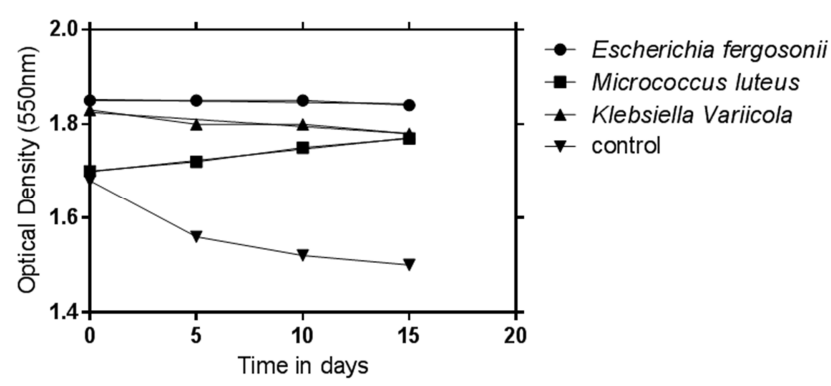

Figure 2. Change in optical density with time in days.

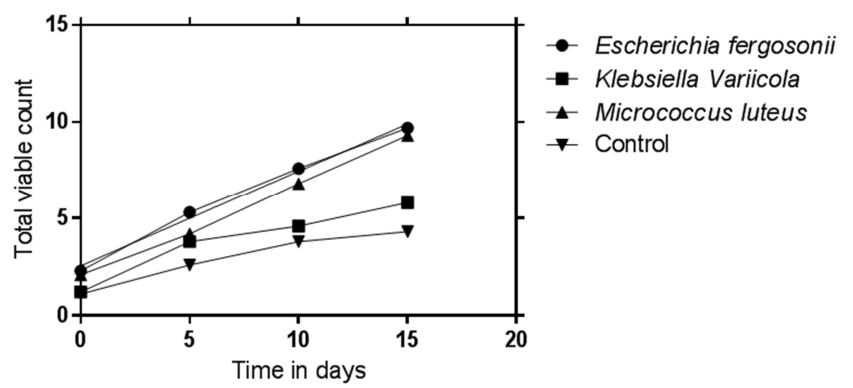

Figure 3. Changes in total viable counts with time in days.

\subsection{Biodegradation Study of Crude Oil}

One and half $\mathrm{ml}$ of culture from inoculums development were added in $500 \mathrm{ml}$ conical flask containing sterilized $1.2 \mathrm{ml}$ crude oil in mineral salt and one flask served as a control were subjected to 15 days incubation at $30^{\circ} \mathrm{C}$, place in an orbital shaker at $180 \mathrm{rpm}$. Samples were drawn at 5 days interval of incubation to measure the $\mathrm{pH}$, total viable count, and optical density at $550 \mathrm{~nm}$ wavelength with a colorimeter. The residual hydrocarbon content was examined/analyzed by gas chromatography as described by [9]. Measurement and observation were recorded.

\subsection{Molecular Identification}

Total of three bacterial isolates were submitted to Centre for Agriculture and Biosciences International (CABI) for microbial identification. Briefly, a unique CABI reference number (IMI number) was assigned to each of the samples. All the original samples were subjected to purity check. All 
procedures were validated and processing undertaken in accordance with CABI's in-house method as documented in TPs 61-68 and TP70. Procedures involved the following steps: Molecular assays were carried out on each sample using nucleic acid as a template. A proprietary formulation [micro LYSIS $®$-PLUS (MLP) Microzone, UK)] was subjected to the rapid heating and cooling of a thermal cycler, to lyse cells and release deoxyribonucleic acid (DNA). Following DNA extraction, polymerase chain reaction (PCR) was employed to amplify copies of the rDNA invitro. The quality of the PCR product was assessed by undertaking gel electrophoresis. PCR purification step was carried out to remove unutilized dNTPs, primers, polymerase and other PCR mixture compounds and obtained a highly purified DNA template for sequencing. This procedure also allowed concentration of low yield amplicons. Sequencing reactions were undertaken using BigDye ${ }^{\circledR}$ Terminator v 3.1 kit from Applied Biosystems (Life Technologies, UK) which utilizes fluorescent labeling of the chain terminator ddNTPs, to permit sequencing. Removal of excess unincorporated dye terminators was carried out to ensure a problem-free electrophoresis of fluorescently labelled sequencing reaction products on the capillary array AB 3130 Genetic Analyzer (DS1) DyeEx ${ }^{\mathrm{TM}}$ 2.0 (Qiagen, UK). Modules containing prehydrated gelfiltration resin were optimized for clean-up of sequencing reactions containing BigDye ${ }^{\circledR}$ terminators. Dye removal was followed by suspension of the purified products in highly deionized formamide $\mathrm{Hi}-\mathrm{Di}^{\mathrm{TM}}$ (Life Technologies, UK) to prevent rapid sample evaporation and secondary structure formation. Samples were loaded onto the AB 3130 Genetic Analyzer and sequencing undertaken to determine the order of the nucleotide bases, adenine, guanine, cytosine, and thymine in the DNA oligonucleotide. Following sequencing, identifications were undertaken by comparing the sequence obtained with those available in European Molecular Biology Laboratory (EMBL) via the European Bioinformatics Institute (EBI).

\subsection{Statistical Analysis}

Statistical analysis was carried out on the values obtained from the experimental study using statistical package for social science (SPSS; version 20.0) and analysis of variance (ANOVA). P-values test of significance carried out at $95 \%$ level of confidence using SPSS.

\section{Results}

\subsection{Physicochemical Parameters of Soil Samples}

The palm oil mill effluent $\mathrm{pH}$ ranged from 6.0-7.0 and temperature range of $28^{\circ} \mathrm{C}-32^{\circ} \mathrm{C}$. Bacterial cell proliferation was quantified by assessing the total viable count which ranged from $2 \times 10^{5}-9 \times 10^{5} \mathrm{cfu} / \mathrm{ml}$. Three bacterial isolates were identified on the basis of their cultural, morphological and biochemical characterization and with reference to Bergey's manual of determinative bacteriology (Table 1).
Table 1. Cultural, Morphological and Biochemical Characteristics of the Bacterial Isolates.

\begin{tabular}{|c|c|c|c|}
\hline \multirow{2}{*}{ Parameters } & \multicolumn{3}{|c|}{ Isolate characteristics } \\
\hline & 1 & 2 & 3 \\
\hline Elevation & Convex & Convex & Convex \\
\hline Margin & Irregular & Undulated & Irregular \\
\hline Colour & Gray & Creamy & Creamy yellow \\
\hline Shape & Regular & Irregular & $\begin{array}{l}\text { Irregular Cluster } \\
\text { (Tetra) }\end{array}$ \\
\hline Gram stain & - & - & + \\
\hline Oxidase & - & - & + \\
\hline $\begin{array}{l}\text { Indole } \\
\text { production }\end{array}$ & + & - & - \\
\hline Methly Red & + & - & - \\
\hline Voges Proskaeur & - & + & - \\
\hline $\begin{array}{l}\text { Citrate } \\
\text { (simmon's) }\end{array}$ & - & + & - \\
\hline Urease & + & + & + \\
\hline Motility & + & - & - \\
\hline Lactose & + & + & + \\
\hline Glucose & + & + & - \\
\hline Maltose & - & + & - \\
\hline Mannitol & + & + & + \\
\hline Sucrose & - & - & - \\
\hline Catalase & + & + & + \\
\hline Starch utilization & - & + & - \\
\hline Galactose & - & + & - \\
\hline Fructose & + & + & - \\
\hline Xylose & + & - & - \\
\hline Isolates identities & $\begin{array}{l}\text { Escherichia } \\
\text { fergusonii }\end{array}$ & $\begin{array}{l}\text { Klebsiella } \\
\text { variicola }\end{array}$ & $\begin{array}{l}\text { Micrococcus } \\
\text { luteus }\end{array}$ \\
\hline
\end{tabular}

\subsection{Bacterial Growth Dynamics}

Microbial hydrocarbon degraders after an initial growth lag in week 1 experienced a steady rate of growth through week 2 to week 4 with an observable decline by week 6 of the study period. $16 \mathrm{~S}$ and ITS rDNA sequencing analyses of the three bacterial isolates reported Escherichia fergosonii, Klebsiella Variicola, and Micrococcus luteus by 16S rDNA sequence analysis using the FASTA algorithm with the Prokaryote database from EBI. Top matches were mainly to the species Escherichia coli and Escherichia fergusonii although the validated type strains of these species did not feature in the top 250 results. However, there were many complete genome studies and published sequences for these species amongst the list of top matches. Several other closely related genera belonging to this family were also suggested with slightly lower probabilites. As there was no clear distinction between genera, identification is given to family level.

Top matches of $>99 \%$ were made to members of this genus and include the validated type strains of $K$. pneumoniae (X87276) with a match of $99.2 \%$ and a sequence from the type strain of Klebsiella variicola DSM 15968 (CP010523) with a match of $100 \%$. Top matches were made to Micrococcus luteus and the validated type strain sequence (AJ536198) gave a match of $99 \%$.

\subsection{TPH Quantification}

The gas chromatographic technique carried out on the sample supernatant revealed that total petroleum hydrocarbon 
(TPH) content was greatest in the control (sample without bacterial seeding) with a value of $4362.60 \mathrm{ml} / \mathrm{kg}$, while the least TPH value was obtained in the sample in which Escherichia fergosonii, was added with value from 7653.69 $\mathrm{mg} / \mathrm{ml}-153.07 \mathrm{mg} / \mathrm{ml}$, showing a significant reduction in the oil content which was expressed statistically at $p>0.05$. The sample in which Klebsiella Variicola was added had higher hydrocarbon loss than the Micrococcus luteus seeded sample but was lower than Escherichia fergosonii, sample. Hyrocarbon loss from $7653.69 \mathrm{mg} / \mathrm{ml}-1301.13 \mathrm{mg} / \mathrm{ml}$ occurred in sample seeded with Klebsiella Variicola while hydrocarbon loss from $7653.69 \mathrm{mg} / \mathrm{ml}-1913.42 \mathrm{mg} / \mathrm{kg}$ in the sample seeded with Micrococcus luteus A remarkably low hydrocarbon loss from $7653.69 \mathrm{mg} / \mathrm{kg}-4362.60 \mathrm{mg} / \mathrm{ml}$ was an indicative of a very slow biodegradative process in the microcosm. There a significant difference in the total hydrocarbon losses among the studied sample at $\mathrm{p}>0.05$. The duration of bacterial isolates exposed to crude oil determined their survival, as only crude oil degrading bacterial isolates had the potentials to tolerate/utilize crude oil as a carbon source. The specific hydrocarbonnoclastic microorganisms degraded phytane and pristine of the crude oil fractions. Escherichia fergosonii was observed to be the most effective bacterial isolate which showed $98 \%$ degradation ability and others; Klebsiella variicola showed $83 \%$ and Micrococcus luteus showed $75 \%$ of crude oil degradation within 15days in respect to the control (sterile liquid mineral salt medium and crude oil without bacterial isolates) which was $43 \%$. The $43 \%$ crude oil loss in the control was attributed to natural process of volatilization which was remarkably low and poor. In other words, the bacterial population did not only speed up the process but resulted in high removal efficiencies.

\section{Discussion}

When accidental or indiscriminate crude oil spillages occur and pollute the natural environments, certain microbial pollution of different strains with the potential to degrade crude oil and other chemical pollutants colonize such environment (10). It is however, an important fact that the mineral salt medium used to culture crude oil (petroleum) degrading possesses significant selective effect on the proliferation of bacterial population (11). Statistical analysis showed a positive correlation between test microbial samples and control with significant value of $p=0.05$.

The study has shown the degradative potentials of certain microbial stains in palm oil mill effluent that are capable of utilizing crude oil and the interrelationship of the microbial strains in the complex environment [12] [13]. A suitable environment that will expedite the degradation of crude oil by certain oleophilic microorganisms; $\mathrm{pH}$, nutrient, $(\mathrm{N}, \mathrm{P}$, $\mathrm{K})$, temperature and other growth factors are often needed to boost this biodegradation action and achieve desired results at a calculated time interval. In this course of research, knowledge obtained could assist in the biodegradation of crude oil contaminated sites by adopting the palm oil mill effluent microbial population as suitable hydrocarbon degraders to aid transformation of oil fractions into harmless compounds which are generally eco-friendly. It is important to note that introduction of bacterial isolates into hydrocarbon containing medium often results in temporary deceleration in growth of such microbial diversity (lag time) and once acclimation in the medium is initiated steady rate of growth is brought about due to utilization of the hydrocarbon contaminant as the sole source of energy and carbon (Log time). Once the hydrocarbon concentration in the microcosm depletes, cell decline often follows and later cell death due to starvation stress exerted on the hydrocarbonoclastic microorganisms that solely depended on the carbon content of the hydrocarbon contaminant [6] [14] [15]. Again, no bioremediation technology has been found to be $100 \%$ effective as the process is known to be accompanied by metabolites production which in itself can become inhibitory to hydrocarbon degraders. In the present study, even the most effective method (i.e. use of Escherichia fergosonii) was not $100 \%$ efficient but a significant removal efficiency (98\%) was achieved. It is for this reason that the essence or goal of bioremediation using either limiting factors addition/biostimulation (nutrients) or use of microorganisms (bioaugmentation) is usually to increase biodegradtion speed and contaminant removal efficiency following a threatened hydrocarbon spill. All the bacterial seeded systems (Escherichia fergosonii, Klebsiella Variicola, Micrococcus luteus) resulted in remarkable hydrocarbon losess $(98 \%, 83 \%$ and $75 \%$ ) respectively except the control $(43 \%)$ which was questionably low and insignificant.

\section{Conclusion}

At the end of this experimental study, hydrocarbon removal under natural system resulted in poor biodegradation performance. Bioaugmentation with some bacterial species generate significant hydrocarbon loses. It was concluded that palm oil mill effluent autochthonous bacterial population had high petroleum hydrocarbon degradation potential. Palm mill effluent therefore, serves as alternative source of exogenous/allochthonous bacterial hydrocarbon degraders with the ability to solving crude oil pollution in contaminated sites and to achieve a condition of immediate hydrocarbon remediation response results, Escherichia fergosonii, Klebsiella Variicola, Micrococcus luteus be used as microbial seeders.

\section{Acknowledgments}

We immensely thank Centre for Agriculture and Biosciences International (CABI) Microbial Identification Services United Kingdom for the molecular identification of the isolates. We also thank International Energy Services (IESL) Itd Port-Harcourt, River State Nigeria, for gas chromatographic analysis. 


\section{References}

[1] Kvenvolden K. A. Cooper C. K.. Natural seepage of crude oil into the marine environment", Geo- marine letters. Vol. 23, 2003, pp. 140-146.

[2] Tanaka, O. H., Venkatswaran, K., Komukai, S., Toki, H., Iwabuchi, T. And Miyachi, S. Ecodynamics of oil degrading bacterial and significance of marine mixed population in the degradation of petroleum compounds. International oil spill conference. 1993, pp. 780-785.

[3] Yoshida, M. H. Michel, L. A. Sazanov, S. Yoshikawa, J. Barber, J. K. Lanyi, S. P. Balashov, V. A. Shuvalov, A. G. Yakovlev, T. A. Shkuropatova, L. G. Vasiheva, A. Y. Shkuropatov, P. Gast, S. D. Dunn, P. A. Delrizzo, Y. Bi, K. S. Wood, D. J. Cipriano, P. Turina, A. Biochimica et Biophsica Acta (BBA)-Bioenergetics, 2006, Vol. 1757, 151-155.

[4] Odu, C. I. I. Microbiology of soil contaminated with petroleum hydrocarbons. The extent of contamination of some soils and microbial properties after contamination. Journal of Institute of Petroleum. 1972, vol 58, pp. 202-208.

[5] Jameel, A. T, Olanrewwaju, A. A. Aerobic biodegradation of oil and grease in palm oil mill effluent using consortium of microorganisms. In: M. D. Z, Alam, A. T, Jameel and A, Amid (eds). Current research and development in biotechnology engineering at International Islamic University Malaysia (IIUM) Vol. III. IIUM Press, Kula Lumpur. 2011, pp. 43-51. ISBN 978967418444

[6] Nwankwegu, A. S., Onwosi, C. O., Orji, M. U., Anaukwu, C. G., Okafor, U. C., Azi, F., Marins, P. E. Reclamation of DPK hydrocarbon polluted agricultural soil using a selected bulking agent. Journal of Environmental Management. 2016, Vol. 172, pp. 136-142.

[7] Obayori, O. S., Ilori, M. O., O. S., Ilori., Adebusoye, M. O., Amund, O. O. and Oyetibe. Microbial population changes in tropical agricultural soil experimentally contaminated with crude oil petroleum. African Journal of Biotechnology. 2008, pp. $4512-4520$.

[8] Okpokwasili, G. C and Okori, B. B. Biodeterioration potentials of Microorganisms isolated from car engine lubricating oil. Tribology International. 1988, Vol. 21, pp. 215-220.

[9] Obuekwe, C. O and Al-zarban. Bioremediation of crude oil polluted in Kuwaiti desert: The role of adherent microorganisms, Environmental International. 2011, Vol. 24, pp. 832-834.

[10] Bartha, R and Atlas, R. M. The Microbiology of Aquatic oil spills. Advance Applied Microbiology Vol. 22, pp. 225-226.

[11] Calomiris, J. T., Austin, B, Walker, J. D. and Colwell, R. R. Enrichment for Estuarine. Petroleum Degrading Bacterial using liquid and solid media. Journal of Applied Bacteriology. 1976. Vol. 41, pp. 135-144.

[12] Pacwa-Plociniczak, M., Plaza, G. A., Pitrowska-seget, Z. M. Monitoring the changes in a bacterial community in petroleum-polluted soil bioaugmented with hydrocarbondegrading strains. Applied Soil Ecology. 2016, Vol. 105, pp. 76-85.

[13] Stordal, I. F., Olsen, A. J., Jenssen, B. M., Netzer, R., Hansen, B. H., Altin, D., Braskstad, O. G. Concentrations of viable oildegrading microorganisms are increased in feces from Calanus finmarchicus feeding in petroleum oil dispersions. Marine pollution Bulletin. 2015, Vol. 98, pp. 69-77.

[14] Ntougias, S., Melidis, P., Navrozidou, E., Tzegkas, F. Diversity and efficiency of anthracene-degrading bacteria isolated from a denitrifying activated sludge system treating municipal wastewater. International Biodeterioration \& Biodegradation. 2015, Vol. 97, pp. 151-158.

[15] Kurachi, K., Hosokawa, R., Takahashi, M., Okuyama, H. The potential of glycerol in freezing preservation of turbine oildegrading bacterial consortium and the ability of the revised consortium to degrade petroleum wastes. International Biodeterioration \& Biodegradation. 2014, Vol. 88, pp. 77-82. 